\title{
Total phenolic, flavonoid, flavonol contents and antioxidant activity of Inca peanut (Plukenetia volubilis $L$.) leaves extracts
}

\author{
${ }^{1,2}$ Wuttisin, N., ${ }^{1}$ Nararatwanchai, T. and ${ }^{1, *}$ Sarikaphuti, A. \\ ${ }^{1}$ School of Anti-Aging and Regenerative Medicine, Mae Fah Luang University, Chiang Rai, Thailand 57100 \\ ${ }^{2}$ School of Cosmetic Science, Mae Fah Luang University, Chiang Rai, Thailand 57100
}

\begin{abstract}
Article history:
Received: 11 July 2020

Received in revised form: 16

August 2020

Accepted: 21 September 2020

Available Online: 20

December 2020
\end{abstract}

\section{Keywords:}

Antioxidant,

Flavonoids,

Inca peanut,

Phenolic,

Plukenetia volubilis L.

DOI:

https://doi.org/10.26656/fr.2017.5(1).346

\begin{abstract}
Inca peanut (Plukenetia volubilis L.) leaves were used to make tea and sold as a local product in Thailand but there is no research on the bioactivity of Inca peanut leaves. The present study was carried out to evaluate the phytochemical constituents and antioxidant activity of Inca peanut leaves. Fresh leaves were extracted with water (FW) and hot water $(\mathrm{FH})$. Dried leaves $(\mathrm{DH})$, roasted leaves $(\mathrm{RH})$ and commercial tea leaves $(\mathrm{CH})$ were extracted with hot water. Their phytochemical constituents, the amount of phenolic compounds (TPC), total flavonoid content (TFC) and total flavonol content (TFoC) were analyzed. The in vitro antioxidant activity was evaluated by 2,2-diphenyl-1-picrylhydrazyl (DPPH) radical scavenging activity and 2,2-azinobis (3-ethylbenzothiazoline 6-sulfonic acid) (ABTS) radical cation scavenging activity. The phytochemical screening revealed the presence of phenols, flavonoids, tannin, cardiac glycosides, steroids, and terpenoids. $\mathrm{RH}$ contained the highest TPC $(21.36 \pm 1.90 \mu \mathrm{g} \mathrm{GAE} / \mathrm{mg})$, TFC $(8.65 \pm 0.16 \mu \mathrm{g} \mathrm{QE} / \mathrm{mg})$, TFoC $(0.249 \pm 0.004 \mu \mathrm{g} \mathrm{QE} / \mathrm{mg})$ and exhibited the most potent antioxidant activity by DPPH assay $\left(\mathrm{IC}_{50}=135.97 \pm 6.71 \mu \mathrm{g} / \mathrm{mL}\right)$ and ABTS assay $\left(\mathrm{IC}_{50}=37.53 \pm 3.87 \mu \mathrm{g} / \mathrm{mL}\right)$. Flavonoid has a positive correlation with DPPH radical scavenging activity. These results suggested that the antioxidant activity of Inca peanut leaves might be attributed to the presence of flavonoid compounds. Roasted leaves extract exhibited the highest antioxidant activities. Therefore, Inca peanut leaves extracts could be considered as a good source of antioxidant and developed as a functional food.
\end{abstract}

\section{Introduction}

Aging is regarded as one of the most common concerns in modern society, and it is a complex certain process in human life. Among the theories purposed for explaining the mechanism of aging, free radical or oxidative stress theory is one of the most accepted (Liguori et al., 2018). The free radical theory of aging purposes that the accumulation of free radical and the declining antioxidant defense leading to oxidative stress. This phenomenon is implicated in the pathogenesis of a variety of human and animal diseases and potentially important contributors to the aging process (Wickens, 2001). For this purpose, the use of antioxidants to prevent aging is important.

Inca peanut (Plukenetia volubilis L.) is a perennial, oleaginous plant of the Euphorbiaceae family. It grows in Amazon region of South America that includes parts of Peru and northwestern Brazil in an environment with water and well-drained acidic soil (Gonzalez-Aspajo et al., 2015). It has a star-shaped fruit capsule which the colour turns from green to blackish brown when the fruit matures. The fruit capsules contain edible dark brown oval seeds. The seeds have been utilized for oil production because they are guaranteed to be beneficial from several types of research. In recent years, there has been growing interest in developing Inca peanut plant as a novel source of oil rich in unsaturated fatty acid. Inca peanut is being developed in Southeast Asia because of its great potential as an economic crop (Chandrasekaran and Liu, 2015). It was introduced in Thailand 6 years ago and widely cultivated in Northern Thailand such as Phayao, Lampang, Chiang Mai, and Chiang Rai due to the appropriate geographical location and climate. The main composition of fatty acids in Inca peanut oil cultivated in Thailand was studied and found the presence of linoleic acid or $\omega 6(45.72 \%)$, linolenic acid or $\omega 3(42.27 \%)$, palmitic acid $(6.42 \%)$ and stearic acid (4.53\%) (Wuttisin, 2017). Some amount of oleic acid or $\omega 9$ (8.7-9.6\%) was also detected (Guillén et al., 2003; 
Follegatti-Romero et al., 2009; Chirinos et al., 2013). It also contains essential amino acids such as cysteine, tyrosine, threonine, and tryptophan as well as vitamin E, polyphenols, and minerals (Wang et al., 2018). Inca peanut oil is now available as edible oil. Roasted seeds were served with salt as a snack, while fresh and cooked leaves were part of traditional dishes in many countries. Inca peanut leaves were used to make tea and sold as local products in Thailand. However, there is no research which studies about the bioactivity of Inca peanut leaves and Inca peanut tea. Hence, the aims of this study were to screen phytochemical components and determine the antioxidant activity of Inca peanut leaves. The data might be useful for supporting the benefit of Inca peanut leaves in the future.

\section{Materials and methods}

\subsection{Chemical and reagents}

Gallic acid, Folin-Ciocalteu's reagent, 2,2-diphenyl1-picrylhydrazyl (DPPH), 2,2-azinobis (3ethylbenzothiazoline 6-sulfonic acid) (ABTS), 6hydroxy-2,5,7,8-tetramethylchroman-2-carboxylic acid (Trolox), ascorbic acid, and quercetin were purchased from Sigma-Aldrich Chemical Co. (St. Louis, Mo., U.S.A.). Other chemicals and reagents used in this study were analytical grades.

\subsection{Plant Materials}

Inca peanut plant was grown in Chiang San, Chiang Rai, Thailand. The leaves (5 months old) were collected during June 2018 (Figure 1). Commercial tea leave was purchased from local product in Baan Tha Khan Thong, Chiang San, Chiang Rai, Thailand. Inca peanut tea was prepared by sun-dried and roasted on pan-fired.
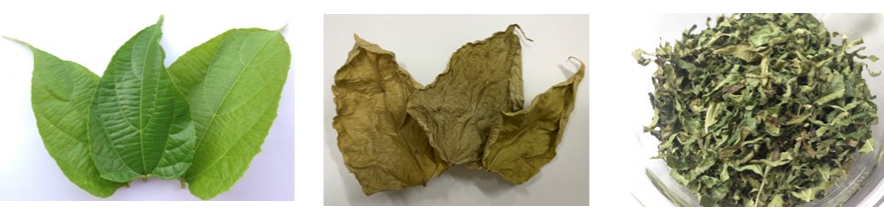

Figure 1. Appearance of Inca peanut leaves (left), dried leaves (middle) and commercial tea leaves (right)

\subsection{Preparation of Inca peanut leaves extracts}

The leaves (fresh or dried) were cut into small pieces by blending in the blender (Sharp/EM-11) and then extracted with water (30 mins) in a ratio of $1: 10(\mathrm{w} / \mathrm{v})$ resulting in five extracts: fresh leaves extracted with water $\left(25^{\circ} \mathrm{C}\right)(\mathrm{FW})$, fresh leaves extracted with hot water $\left(90^{\circ} \mathrm{C}\right)(\mathrm{FH})$, dried leaves (air-dried under shade for 7 days) extracted with hot water $\left(90^{\circ} \mathrm{C}\right)(\mathrm{DH})$, roasted leaves (hot air oven $60^{\circ} \mathrm{C}, 48 \mathrm{hrs}$ ) extracted with hot water $\left(90^{\circ} \mathrm{C}\right)(\mathrm{RH})$ and commercial tea leaves extracted with hot water $\left(90^{\circ} \mathrm{C}\right)(\mathrm{CH})$. The extracts were then filtered through Whatman ${ }^{\circledR}$ paper No.1 and dried using freeze dryer (Labconco). The percentages of yield were calculated by the following equation:

$\%$ Yield $=[$ Inca peanut extract $(\mathrm{g}) /$ Inca peanut leaves $(\mathrm{g})] \times 100$

\subsection{Phytochemical screening of Inca peanut leaves extracts}

Inca peanut leaves extracts were dissolved in water $(5 \mathrm{mg} / \mathrm{mL}$ ) and determined for their phytochemical constituents as following.

\subsubsection{Test for phenols}

$5 \%$ ferric chloride solution $(0.2 \mathrm{~mL})$ was added into test tube containing $1 \mathrm{~mL}$ of the extract. The purple colour indicates the presence of phenolic compounds (Harborne, 1973).

\subsubsection{Test for saponins}

The extract $(2 \mathrm{~mL})$ was added into the test tube containing $2 \mathrm{~mL}$ of distilled water. The mixture was shaken vigorously for 2 mins and warmed $\left(37^{\circ} \mathrm{C}\right)$. The formation of stable foam indicates the presence of saponins (Banso and Adeyemo, 2006).

\subsubsection{Test for flavonoids}

\subsubsection{Alkaline reagent test}

$10 \%$ sodium hydroxide solution $(0.2 \mathrm{~mL})$ was added into $1 \mathrm{~mL}$ of the extract. The intense yellow colour indicates the presence of flavonoids (Tiwari et al., 2011).

\subsubsection{Lead acetate test}

$10 \%$ lead acetate solution $(0.2 \mathrm{~mL})$ was added into 1 $\mathrm{mL}$ of the extract. The white or yellow precipitate indicates the presence of flavonoids (Bargah, 2015).

\subsubsection{Test for steroids}

According to Salkowski's test, $1 \mathrm{~mL}$ of the extract was mixed with $1 \mathrm{~mL}$ of chloroform and $1 \mathrm{~mL}$ of concentrated sulfuric acid. The red colour in the lower chloroform layer indicates the presence of steroids (Harborne, 1973).

\subsubsection{Test for terpenoids}

The extract $(2 \mathrm{~mL})$ was dissolved in $2 \mathrm{~mL}$ of chloroform and evaporated to dryness. Concentrated sulfuric acid $(5 \mathrm{~mL})$ was then added and heated for 2 mins. Development of a grayish colour indicates the presence of terpenoids (Bargah, 2015). 


\subsubsection{Test for alkaloid}

Potassium iodide ( $2 \mathrm{~g})$ and iodine $(1.27 \mathrm{~g})$ were dissolved in distilled water $(5 \mathrm{~mL})$ and the solution was diluted to $100 \mathrm{~mL}$ with distilled water. An aliquot $(0.5$ $\mathrm{mL}$ ) of this solution was added to $1 \mathrm{~mL}$ of the extract (50 $\mathrm{mg} / \mathrm{mL}$ ). A brown colored precipitate indicates the presence of alkaloids (Abdullahi et al., 2013; Joshi et al., 2013).

\subsubsection{Test for tannins}

Leave extract $(50 \mathrm{mg})$ was separately dissolved in distilled water $(10 \mathrm{~mL})$. The mixture is boiled for five mins and then filtered. The filtrate was added with 0.5 $\mathrm{mL}$ of $5 \%$ ferric chloride. Black or blue-green colouration or precipitate was taken as a positive result for the presence of tannins (Akinjogunla et al., 2010).

\subsubsection{Test for glycosides}

Leave extract $(0.5 \mathrm{~g})$ was shaken with distilled water $(5 \mathrm{~mL})$. Glacial acetic acid $(2 \mathrm{~mL})$ containing one drop of $5 \%$ ferric chloride was added, followed by concentrated sulfuric acid $(1 \mathrm{~mL})$ along the side of the test tube. The formation of a brown ring at the interface gives a positive indication for cardiac glycoside and a violet ring may appear below the brown ring (Ayoola et al., 2008).

\subsection{Determination of total phenolic contents (TPC)}

The amount of TPC was determined according to the method described by Waterman and Mole (1994) with some modifications. Inca peanut leaves extracts were dissolved in water $(2 \mathrm{mg} / \mathrm{mL})$ and determined for their TPC. Each extract $(20 \mu \mathrm{L})$ was added with FolinCiocalteu reagent $(100 \mu \mathrm{L})$. Three mins later, $7.5 \% \mathrm{w} / \mathrm{v}$ sodium carbonate $(80 \mu \mathrm{L})$ was added into the mixture which was then shaken and allowed to stand for $1 \mathrm{hr}$ at ambient temperature. After incubation time, the absorbance was measured at $760 \mathrm{~nm}$ (SPECTROstar Nano Microplate Reader, BMG Labtech). Gallic acid was used as a reference compound. A calibration curve of gallic acid was prepared in the range of 1 to $10 \mu \mathrm{g} /$ $\mathrm{mL}$. The result was expressed as $\mu \mathrm{g}$ gallic acid equivalent per mg of extract ( $\mu \mathrm{g} \mathrm{GAE} / \mathrm{mg}$ ).

\subsection{Determination of total flavonoid content (TFC)}

Inca peanut leaves extracts were dissolved in water ( $2 \mathrm{mg} / \mathrm{mL}$ ) and determined for their TFC. TFC was determined using the aluminum colorimetric method with some modifications using quercetin as the standard (Iqbal et al., 2015). A calibration curve of quercetin was prepared in the range of 0.5 to $12 \mu \mathrm{g} / \mathrm{mL}$. Briefly, extract $(100 \mu \mathrm{L})$ or standard $(100 \mu \mathrm{L})$ were placed in different test tubes and $10 \%$ aluminum chloride $(50 \mu \mathrm{L}), 1 \mathrm{M}$ potassium acetate $(50 \mu \mathrm{L}), 80 \%$ methanol $(750 \mu \mathrm{L})$ and distilled water $(1.4 \mathrm{~mL})$ were added and mixed. A blank was prepared in the same manner where $100 \mu \mathrm{L}$ of distilled water was used instead of the sample or standard, and the amount of aluminum chloride was also replaced by distilled water. All tubes were incubated at room temperature for 30 mins. The absorbance was taken at $415 \mathrm{~nm}$ (UV-VIS Spectrophotometer, Thermo Scientific). The concentration of flavonoid was expressed as $\mu \mathrm{g}$ quercetin equivalent per $\mathrm{mg}$ of extract ( $\mu \mathrm{g} \mathrm{QE} / \mathrm{mg}$ ).

\subsection{Determination of total flavonol content (TFoC)}

Inca peanut leaves extracts were dissolved in water $(2 \mathrm{mg} / \mathrm{mL}$ ) and determined for their TFoC. TFoC content was analyzed using aluminum chloride colorimetric method with some modifications (Pattanayak et al., 2011; Pallab et al., 2013). In this method, quercetin was used to make a standard calibration curve in the range of 0.5 to $4 \mu \mathrm{g} / \mathrm{mL}$. In different test tubes, each extract (100 $\mu \mathrm{L})$ and standard solutions $(100 \mu \mathrm{L})$ were placed and then $2 \%$ aluminum chloride $(300 \mu \mathrm{L}), 5 \%$ sodium acetate $(0.9 \mathrm{~mL})$ were added and mixed well. All tubes were incubated at room temperature for 20 mins. The absorbance of standard and sample was taken at $440 \mathrm{~nm}$. Results were expressed as $\mu \mathrm{g}$ quercetin equivalent per $\mathrm{mg}$ of extract ( $\mu \mathrm{g} \mathrm{QE} / \mathrm{mg})$.

\subsection{Determination of antioxidant activities}

Inca peanut leaves extracts were dissolved in water at various concentrations $(2.0,1.0,0.5,0.25$ and 0.125 $\mathrm{mg} / \mathrm{mL}$ ) and determined for their antioxidant activities as following.

\subsubsection{DPPH radical $\left(D P P H^{\circ}\right)$ scavenging activity}

DPPH scavenging activity was determined according to colorimetric method with some modifications (Gülçin et al., 2003). Each sample was prepared by mixing $20 \mu \mathrm{L}$ of each extract with $180 \mu \mathrm{L}$ of DPPH solution $(0.1$ $\mathrm{mmol} / \mathrm{L}$ ). A mixture containing $180 \mu \mathrm{L}$ of $\mathrm{DPPH}$ solution and $20 \mu \mathrm{L}$ of $95 \%$ ethanol was used as control. After incubation in the dark place for $30 \mathrm{~min}$, the absorbance of each mixture was measured spectrometrically at $517 \mathrm{~nm}$ (SPECTROstar Nano Microplate Reader, BMG Labtech). Trolox was used as a reference compound. Similar concentration extract without DPPH solution was used as the blank to eliminate interference. The ability to scavenge the $\mathrm{DPPH}^{*}$ was calculated by the following equation:

$$
\% \mathrm{DPPH}^{*} \text { scavenging }=[\mathrm{A} 0-(\mathrm{A} 1-\mathrm{A} 2) / \mathrm{A} 0] \times 100
$$

Where A0 $=$ Absorbance of the control without standard 
or sample, $\mathrm{A} 1=$ Absorbance of the mixture containing standard or samples, and A2 $=$ Absorbance of the blank (extract without DPPH solution)

The calibrations curve between the percent inhibition and the trolox concentration was established. The DPPH ${ }^{*}$ scavenging activity was expressed as trolox equivalent antioxidant capacity ( $\mu \mathrm{g}$ TEAC/mg) and $\mathrm{IC}_{50}$ values $(\mu \mathrm{g} /$ $\mathrm{mL}$ ), indicating the concentrations of extracts scavenge $50 \%$ of $\mathrm{DPPH}^{\circ}$.

\subsubsection{ABTS radical cation $\left(A B T S^{\circ+}\right)$ scavenging activity}

The antioxidant activity was determined by ABTS scavenging activity with some modifications (Re et al., 1999). The stock solution of ABTS cation chromophore was prepared by the reaction between $7 \mathrm{mM}$ ABTS solution $(100 \mathrm{~mL})$ and $2.45 \mathrm{mM}$ potassium persulfate (final concentration) $(100 \mathrm{~mL})$ in the dark place at ambient temperature for $16 \mathrm{~h}$. The $\mathrm{ABTS}^{\circ+}$ solution was diluted with phosphate buffer $(50 \mathrm{mM}, \mathrm{pH} 7.4)$ to an absorbance of $0.70 \pm 0.02$ at $734 \mathrm{~nm}$. A mixture containing $180 \mu \mathrm{L}$ of ABTS $^{\circ+}$ solution and $20 \mu \mathrm{L}$ of phosphate buffer was used as control. The extract (20 $\mu \mathrm{L})$ was added to $180 \mu \mathrm{L}$. ABTS $^{{ }^{+}}$solution and incubated for $30 \mathrm{~min}$ at ambient temperature. The absorbance was measured at $734 \mathrm{~nm}$ (SPECTROstar Nano Microplate Reader, BMG Labtech). Ascorbic acid was used as a reference compound. Similar concentration extract without $\mathrm{ABTS}^{\cdot+}$ solution was used as the blank to eliminate interference. The percent inhibition of $\mathrm{ABTS}^{{ }^{++}}$ was calculated by the following equation:

$$
\% \mathrm{ABTS}^{\cdot+} \text { scavenging }=[\mathrm{A} 0-(\mathrm{A} 1-\mathrm{A} 2) / \mathrm{A} 0] \times 100
$$

Where $\mathrm{A} 0=$ Absorbance of the control without standard or sample, $\mathrm{A} 1=$ Absorbance of the mixture containing standard or samples, and A2 $=$ Absorbance of the blank (extract without $\mathrm{ABTS}^{\circ+}$ solution)

The calibrations curve between the percent inhibition and the ascorbic acid concentration was established. The $\mathrm{ABTS}^{++}$scavenging activity was expressed as mg ascorbic acid equivalent antioxidant capacity per gram extract (mg AEAC/g) and $\mathrm{IC}_{50}$ values $(\mu \mathrm{g} / \mathrm{mL})$, indicating the concentrations of extracts scavenge $50 \%$ of $\mathrm{ABTS}^{*+}$.

\subsection{Statistical analysis}

All assays were performed triplicate in three independent and separate experiments. The data were presented as mean \pm standard deviations (SD). SPSS 23.0 was employed for all data analyses. One-way analysis of variance (ANOVA) Post Hoc multiple comparisons by Duncan's multiple range test was used to evaluate the difference between sample groups. The level of significance was at $\mathrm{P}<0.05$. A linear correlation analysis was performed in order to determine the relationship between TPC, TFC, TFoC and antioxidant activities.

\section{Results and discussion}

\subsection{Phytochemical screening of Inca peanut leaves extracts}

The phytochemical screening of the Inca peanut leaves extracts revealed the presence of some active compounds such as phenols, flavonoids, tannins, cardiac glycosides, steroids, and terpenoids as shown in Table 1 . Phenol is considered the simplest class of phenolic compounds. Flavonoids are the largest group of plant phenols. Tannins are compounds of high molecular weight phenolic polymers which are found commonly in grapes, tea and legume (Saxena et al., 2013). Cardiac glycosides are steroids having the ability to exert specific powerful action on the cardiac muscle valuable in the treatment of congestive heart failure. It could be also found in some plants belonging to Euphorbiaceae (Hollman, 1985). Steroids and terpenoids were reported to be active against antibacterial activity (Bargah, 2015). The same finding was reported by Nascimento et al. (2013) that they described the presence of phenolic compounds, flavonoids, steroid and terpenoids in Inca peanut leaves. These phytochemicals are known to possess therapeutic activities including antimicrobial, cytotoxicity, anti-inflammatory, antitumor activity, anticarcinogenic and antioxidant with beneficial effects in the human diet. Only fresh leaves extracts contain saponins and alkaloids which were in accordance with the previously studied that roasting enables the reduction of saponins and alkaloids which are considered as phytotoxins then it was recommended to avoid high and chronic consumption of fresh leaves (Srichamnong et al., 2018). The preliminary phytochemical screening tests

Table 1. Phytochemical screening of Inca peanut leaves extracts

\begin{tabular}{lccccc}
\hline & FW & FH & DH & RH & CH \\
\hline Phenols & + & + & + & + & +
\end{tabular}

Flavonoids

$\begin{array}{llllll}\text { Alkaline reagent test } & + & + & + & + & + \\ \text { Lead acetate test } & + & + & + & + & + \\ \text { Tannins } & + & + & + & + & + \\ \text { Glycosides } & + & + & + & + & + \\ \text { Steroids } & + & + & + & + & + \\ \text { Terpenoids } & + & + & + & + & + \\ \text { Saponins } & - & + & - & - & - \\ \text { Alkaloids } & + & - & - & - & -\end{array}$

Where, + indicates the presence of phytochemicals, and indicates the absence of phytochemicals. 
help to detect the bioactive compounds. Further steps such as purification and characterization are necessary.

\subsection{TPC of Inca peanut leaves}

Extraction yields of Inca peanut leaves are given in Table 2. After extraction, DH and RH provided a higher yield than FW and FH. There are no studies in the previous works of literature concerning yields of Inca peanut leaves extracts. TPC of Inca peanut leaves was estimated and the result revealed in Table 2 that DH, RH and FW exhibited a high significance level $(\mathrm{P}<0.05)$ of TPC followed by $\mathrm{FH}$ and $\mathrm{CH}$. Phenolic compounds are the largest category of phytochemicals and the most widely distributed in the plant kingdom (Saxena et al., 2013). They are mostly composed of flavonoids, phenolic acids, stilbenes, coumarins and tannins (Islam et al., 2015). Phenolic compounds have redox properties, which allow them to act as antioxidants (Soobrattee et al., 2005). Their antioxidant ability is facilitated by their hydroxyl groups via scavenging or stabilizing free radical through hydrogenation or complexion with oxidizing species (Uddin et al., 2020). TPC could be used as a basis for rapid screening of antioxidant activity. Inca peanut seeds have been assessed for TPC ranging from 64.6 to $80 \mathrm{mg} \mathrm{GAE} / 100 \mathrm{~g}$ which is lower than in leaves extract 20 folds (Wuttisin, 2017).

\subsection{TFC of Inca peanut leaves}

$\mathrm{DH}$ and $\mathrm{RH}$ exhibited the highest $(\mathrm{P}<0.05)$ TFC followed by $\mathrm{CH}$ while $\mathrm{FH}$ and $\mathrm{FW}$ exhibited the lowest TFC (Table 2). Flavonoids are probably the most important natural phenolics. TFC in the extract was determined by the spectrophotometric method with aluminum chloride. The flavonoids combine with aluminum to form a complex flavonoid-aluminum that could be measured at $415 \mathrm{~nm}$ (Quettier, 2000). The most abundant flavonoid which has a good antioxidant property is quercetin.

\subsection{TFo Co Inca peanut leaves}

Table 2 shows that RH and FW exhibited the highest TFoC $(\mathrm{P}<0.05)$ followed by $\mathrm{DH}, \mathrm{CH}$ and FH. Flavonols are one type of flavonoids. TFoC was less in all extracts. In this study, RH exhibited the highest TPC, TFC and TFoC when compared to other extracts. However, further research is needed to identify the flavonoids and flavonols components in Inca peanut leaves.

\subsection{Antioxidant activities}

\subsubsection{DPPH scavenging activity}

The free radical scavenging activities of the extracts were determined using DPPH scavenging assay and the results were displayed in Table 3 . The results were expressed with TEAC range from $58.49 \pm 3.47$ to $70.77 \pm 2.35 \mathrm{mg} \mathrm{TEAC} / \mathrm{g}$. The significant highest antioxidant activity $(\mathrm{P}<0.05)$ is from $\mathrm{DH} \quad\left(\mathrm{IC}_{50}=\right.$ $134.35 \pm 5.07 \mu \mathrm{g} / \mathrm{mL})$ and $\mathrm{RH}\left(\mathrm{IC}_{50}=135.97 \pm 6.71 \mu \mathrm{g} /\right.$ $\mathrm{mL}$ ) as compared with other extracts. DPPH scavenging method offers the first approach for evaluating the antioxidant potential of plant extract. This assay measures the ability of the plant extract to donate an electron or $\mathrm{H}^{+}$ion. The $\mathrm{DPPH}^{*}$ is a stable free radical and

Table 2. Total phenolic, total flavonoid and total flavonol contents of Inca peanut leaves extracts

\begin{tabular}{ccccc}
\hline Extracts & $\%$ Yield & $\begin{array}{c}\text { Total phenolic } \\
\text { content } \\
(\mu \mathrm{g} \mathrm{GAE} / \mathrm{mg})\end{array}$ & $\begin{array}{c}\text { Total flavonoid } \\
\text { content } \\
(\mu \mathrm{g} \mathrm{QE} / \mathrm{mg})\end{array}$ & $\begin{array}{c}\text { Total flavonol } \\
\text { content } \\
(\mu \mathrm{g} \mathrm{QE} / \mathrm{mg})\end{array}$ \\
\hline FW & 10.26 & $21.29 \pm 0.89^{\mathrm{a}}$ & $4.34 \pm 0.61^{\mathrm{c}}$ & $0.235 \pm 0.005^{\mathrm{a}}$ \\
$\mathrm{FH}$ & 8.68 & $16.94 \pm 1.80^{\mathrm{b}}$ & $4.75 \pm 0.12$ & $0.111 \pm 0.016^{\mathrm{d}}$ \\
$\mathrm{DH}$ & 19.34 & $21.48 \pm 0.72^{\mathrm{a}}$ & $8.78 \pm 0.15^{\mathrm{a}}$ & $0.194 \pm 0.017^{\mathrm{b}}$ \\
$\mathrm{RH}$ & 19.29 & $21.36 \pm 1.90^{\mathrm{a}}$ & $8.65 \pm 0.16^{\mathrm{a}}$ & $0.249 \pm 0.004^{\mathrm{a}}$ \\
$\mathrm{CH}$ & 17.83 & $13.79 \pm 0.82^{\mathrm{c}}$ & $6.74 \pm 0.04^{\mathrm{b}}$ & $0.151 \pm 0.041^{\mathrm{c}}$ \\
\hline
\end{tabular}

Values were presented as mean \pm SD of three independent measurements. Different letters in the same column indicates significant differences $(\mathrm{P}<0.05)$

Table 3. DPPH scavenging activity and ABTS scavenging activity of Inca peanut leaves extracts

\begin{tabular}{lcccc}
\hline & $\begin{array}{c}\text { DPPH } \\
(\mathrm{mg} \mathrm{TEAC} / \mathrm{g})\end{array}$ & $\begin{array}{c}\mathrm{IC}_{50}(\mathrm{DPPH}) \\
(\mu \mathrm{g} / \mathrm{mL})\end{array}$ & $\begin{array}{c}\text { ABTS } \\
(\mathrm{mg} \text { AEAC } / \mathrm{g})\end{array}$ & $\begin{array}{c}\mathrm{IC}_{50}(\mathrm{ABTS}) \\
(\mu \mathrm{g} / \mathrm{mL})\end{array}$ \\
\hline FW & $58.49 \pm 3.47^{\mathrm{b}}$ & $148.30 \pm 7.17^{\mathrm{b}}$ & $135.92 \pm 2.79^{\mathrm{a}}$ & $39.59 \pm 1.57^{\mathrm{a}}$ \\
$\mathrm{FH}$ & $60.11 \pm 0.62^{\mathrm{b}}$ & $147.49 \pm 3.42^{\mathrm{b}}$ & $121.61 \pm 3.02^{\mathrm{b}}$ & $43.58 \pm 1.89^{\mathrm{bc}}$ \\
$\mathrm{DH}$ & $68.15 \pm 2.57^{\mathrm{a}}$ & $134.35 \pm 5.07^{\mathrm{a}}$ & $118.12 \pm 3.04^{\mathrm{b}}$ & $44.72 \pm 2.60^{\mathrm{c}}$ \\
$\mathrm{RH}$ & $70.77 \pm 2.35^{\mathrm{a}}$ & $135.97 \pm 6.71^{\mathrm{a}}$ & $138.36 \pm 5.24^{\mathrm{a}}$ & $37.53 \pm 3.87^{\mathrm{a}}$ \\
$\mathrm{CH}$ & $59.84 \pm 1.70^{\mathrm{b}}$ & $149.42 \pm 3.40^{\mathrm{b}}$ & $122.31 \pm 5.96^{\mathrm{b}}$ & $42.19 \pm 2.78^{\mathrm{b}}$ \\
Trolox & - & $6.96 \pm 0.60$ & - & - \\
Ascorbic acid & - & - & - & $3.88 \pm 0.50$ \\
\hline
\end{tabular}

Values were presented as mean $\pm \mathrm{SD}$ of three independent measurements. Different letters in the same column indicates significant differences $(\mathrm{P}<0.05)$ 
shows maximum absorbance at $517 \mathrm{~nm}$. DPPH ${ }^{*}$ accepts electron or hydrogen from antioxidant molecules to become a stable molecule resulting in a decrease in absorbance (Ahmed et al., 2013). With reference to the positive control Trolox, the scavenging ability of the Inca Peanut leaves extracts on $\mathrm{DPPH}^{\bullet}$ was shown. The lower the $\mathrm{IC}_{50}$ values are, the higher the antioxidant capacity of the leaves extracts become. Inca Peanut leaves contain flavonoids, flavonols and related polyphenols are able of donating a hydrogen atom to a free radical to neutralize it.

\subsubsection{ABTS scavenging activity}

Table 3 shows the antioxidant activities of Inca peanut leaves extract determined by ABTS scavenging activity. The results revealed that RH and FW exhibited the highest antioxidant activities $(\mathrm{P}<0.05)$ with the $\mathrm{IC}_{50}$ values of $37.53 \pm 3.87 \mu \mathrm{g} / \mathrm{mL}$ and $39.59 \pm 1.57 \mu \mathrm{g} / \mathrm{mL}$, respectively. ABTS scavenging assay depends on the antioxidant compound ability to scavenge $\mathrm{ABTS}^{{ }^{*+}}$. This assay can measure the antioxidant capacity of hydrophilic compounds (Awika et al., 2003). In the same way, ABTS inhibition mechanism was similar to DPPH scavenging assay. We observed that RH exhibited more potent antioxidant activity than other extracts when determined by DPPH and ABTS scavenging assay, then it is the most interesting for further roles in healthpromoting as an antioxidant.

\subsection{Correlation between TPC, TFC, TFoC and antioxidant activity}

The correlation between the TPC, TFC, TFoC and their antioxidant activities were done and displayed in correlation coefficients $\left(\mathrm{R}^{2}\right)$ values from linear regression analysis (Table 4). A positive correlation was observed between antioxidant activity and phenolic compounds. The results showed that flavonoid has a positive correlation with DPPH antioxidant activity $\left(\mathrm{R}^{2}=\right.$ 0.8153 ) while flavonols have a positive correlation with ABTS antioxidant activity $\left(\mathrm{R}^{2}=0.6051\right)$. The correlation indicated that the richness in phenolic compounds especially higher flavonoids contents lead to better DPPH scavenging activity (Felhi et al., 2016). The results suggested that the antioxidant activity of Inca peanut leaves might be attributed to the presence of flavonoids which are more react with $\mathrm{DPPH}^{*}$ better than ABTS $^{+}$(Wuttisin and Boonsook, 2019). Thus, flavonoids can be used to predict the antioxidant activity of Inca peanut leaves. The positive correlation between flavonol content and ABTS antioxidant activity strengthens the results observed in the DPPH. This investigation confirms that an increase in total phenolic compounds will increase the antioxidant activity of extracts which in accordance with previously reported
(Bakari et al., 2015). Polyphenols have a metal chelating potential and their redox properties can be justified by their chemical structure (Li et al., 2008; Schvab et al., 2015). For this reason, the high polyphenolic content in the extracts may explain the high antioxidant activity of the extracts. In addition, the antioxidant activity might be attributed to the presence of non-phenolic compounds and Inca peanut leaves might be contained other synergistic or antagonistic compounds (Tomsone et al., 2012). Further studies are required to identify other chemical components in Inca peanut leaves. The presence of flavonoids such as quercetin and other phytochemicals are recommended to be characterized by HPLC analysis. Furthermore, quercetin is suggested to use as a reference compound in DPPH and ABTS radical scavenging activity for prediction the antioxidant activity of Inca peanut leaves due to the positive correlation between flavonoid and antioxidant activity.

Table 4. Correlation matrix of phenolic, flavonoids, flavonols and antioxidant activities against DPPH and ABTS radical

\begin{tabular}{lcccc}
\hline Parameters & ABTS & DPPH & Flavonols & Flavonoids \\
\hline Phenolic & 0.226 & 0.3111 & 0.5953 & 0.0787 \\
Flavonoids & 0.0082 & 0.8153 & 0.1234 & \\
Flavonols & 0.6051 & 0.242 & & \\
DPPH & 0.0245 & & & \\
\hline
\end{tabular}

\section{Conclusion}

The result of this study shows the presence of some phytochemicals such as phenols, flavonoids, tannin, cardiac glycosides, steroids, and triterpene in Inca peanut leaves extracts. Roasting enables the reduction of saponins and alkaloids in Inca peanut leaves extracts. Roasted leave extract with hot water exhibited the highest phenolic, flavonoids, and flavonols contents. The result also revealed that roasted leaves extract showed the highest antioxidant activity by DPPH assay and ABTS assay. The antioxidant properties of the extracts might be due to the presence of flavonoid and other phytochemicals present in Inca peanut leaves. Therefore, Inca peanut leaves and Inca peanut tea could be consumed as a source of antioxidant for preventing free radicals mediated oxidative stress. This is an ongoing study and further work is being carried to investigate its biological activities.

\section{Conflict of interest}

The authors declare no conflict of interest.

\section{Acknowledgments}

This study was supported by Mae Fah Luang University's grant, Chiang Rai, Thailand. 


\section{References}

Abdullahi, M.N., Ilyas, N. and Ibrahim, H. (2013). Evaluation of phytochemical screening and analgesic activity of aqueous extract of the leaves of Microtrichia perotitii Dc (Asteraceae) in mice using hotplate method. Medicinal Plant Research, 3(5), 37 -43. https://doi.org/10.5376/mpr.2013.03.0005

Ahmed, D., Zara, S. and Baig, H. (2013). In vitro analysis of antioxidant activities of Oxalis Corniculata Linn. fractions in various solvents. African Journal of Traditional, Complementary and Alternative Medicines, 10(1), 158-165. https:// doi.org/10.4314/ajtcam.v10i1.21

Akinjogunla, O.J., Yah, C.S., Eghafona, N.O. and Ogbemudia, F.O. (2010). Antibacterial activity of leave extracts of Nymphaea lotus (Nymphaeaceae) on Methicillin-resistant Staphylococcus aureus (MRSA) and Vancomycin-resistant Staphylococcus aureus (VRSA) isolated from clinical samples. Annals of Biological Research, 1(2), 174-184.

Awika, J.M., Rooney, L.W., Wu, X., Prior, R.L. and Cisneros-Zevallos, L. (2003). Screening methods to measure antioxidant activity of Sorghum (Sorghum bicolour) and Sorghum products. Journal of Agricultural and Food Chemistry, 51(23), 66576662. https://doi.org/10.1021/jf034790i

Ayoola, G.A., Coker, H.A.B., Adesegun, S.A., AdepojuBello, A.A., Obaweya, K., Ezennia, E.C. and Atangbayila, T.O. (2008). Phytochemical screening and antioxidant activities of some selected medicinal plants used for Malaria therapy in Southwestern Nigeria. Tropical Journal of Pharmaceutical Research, 7(3), 1019-1024. https://doi.org/10.4314/ tjpr.v7i3.14686

Bakari, S., Ncir, M., Felhi, S., Hajlaoui, H., Saoudi, M., Gharsallah N. and Kadri, A. (2015). Chemical composition and in vitro evaluation of total phenolic, flavonoid and antioxidant properties of essential oil and solvent extract from the aerial parts of Teucrium polium grown in Tunisia. Food Science and Biotechnology, 24(6), 1943-1949. https:// doi.org/10.1007/s10068-015-0256-Z

Banso, A. and Adeyemo, S. (2006). Phytochemical screening and antimalarial assessment of Abutilon mauritianum, Bacopa monnifera and Datura stramonium. Biokemistri, 18, 39-44. https:// doi.org/10.4314/biokem.v18i1.56390

Bargah, R.K. (2015). Preliminary test of phytochemical screening of crude ethanolic and aqueous extract of Moringa pterygosperma Gaertn. Journal of Pharmacognosy and Phytochemistry, 4(1), 7-9.

Chandrasekaran, U. and Liu, A. (2015). Stage-specific metabolization of triacylglycerols during seed germination of Sacha Inchi (Plukenetia volubilis L.). Journal of the Science of Food and Agriculture, 95 (8), 1764-1766. https://doi.org/10.1002/jsfa.6855

Chirinos, R., Zuloeta, G., Pedreschi, R., Mignolet, E., Larondelle, Y. and Campos, D. (2013). Sacha inchi (Plukennetia valubilis): A seed source of polyunsaturated fatty acids, tocopherols, phytosterols, phenolic compounds and antioxidant capacity. Food Chemistry, 141(3), 1732-1739. https://doi.org/10.1016/j.foodchem.2013.04.078

Felhi, S., Baccouch, N., Ben Salah, H., Smaoui, S., Allouche, N., Gharsallah, N. and Kadri, A. (2016). Nutritional constituents, phytochemical profiles, in vitro antioxidant and antimicrobial properties and gas chromatography-mass spectrometry analysis of various solvent extracts from grape seeds (Vitis vinifera L.). Food Science and Biotechnology, 25(6), 1537-1544. https://doi.org/10.1007/s10068-016-0238 $-9$

Follegatti-Romero, L.A., Piantino, C.R., Grimaldi, R. and Cabral, F.A. (2009). Supercritical $\mathrm{CO}_{2}$ extraction of omega-3 rich oil from Sacha inchi (Plukennetia volubilis L.) seeds. The Journal of Supercritical Fluids, 49(3), 323-329. https:// doi.org/10.1016/j.supflu.2009.03.010

Gonzalez-Aspajo, G., Belkhelfa, H., Haddioui-Hbabi, L., Bourdy, G. and Deharo, E. (2015). Sacha inchi oil (Plukenetia volubilis L.) effect on adherence of Staphylococus aureus to human skin explant and keratinocytes in vitro. Journal of Ethnopharmacology, 171, 330-334. https:// doi.org/10.1016/j.jep.2015.06.009

Guillén, M., Ruiz, A., Cobo, N., Chirinos, R. and Pascual, G. (2003). Characterization of Sacha inchi (Plukennetia volubilis L.) oil by FTIR spectroscopy and 'H NMR comparison with Linseed oil. Journal of the American Oil Chemists' Society, 80(8), 755762. https://doi.org/10.1007/s11746-003-0768-z

Gülçin, İ., Oktay, M., Kıreçci, E. and Küfrevioğlu, Ö. (2003). Screening of antioxidant and antimicrobial activities of anise (Pimpella anisum L.) seed extracts. Food Chemistry, 83(3), 371-382. https:// doi.org/10.1016/S0308-8146(03)00098-0

Harborne, J.B. (1973). Phytochemical methods: a guide to modern techniques of plant analysis. New York: Chapman and Hall. https://doi.org/10.1007/978-94009-5921-7_1

Hollman, A. (1985). Plants and cardiac glycosides. British Heart Journal, 54, 258-261. https:// doi.org/10.1136/hrt.54.3.258

Iqbal, E., Salim, K.A. and Lim, L.B.L. (2015). 
Phytochemical screening, total phenolics and antioxidant activities of bark and leaf extracts of Goniothalamus velutinus (Airy Shaw) from Brunei Darussalam. Journal of King Saud UniversityScience, 27(3), 224-232. https://doi.org/10.1016/ j.jksus.2015.02.003

Islam, M.Z., Hoque, M.M., Asif-Ul-Alam, S.M. and Monalisa, K. (2015). Antioxidant capacities and storage stability of Citrus macroptera and Garcinia pedunculata fruits. Emirates Journal of Food and Agriculture, 27(3), 275-282. https://doi.org/10.9755/ ejfa.v27i3.18624

Joshi, A., Bhobe, M. and Saatarkar, A. (2013). Phytochemical investigation of the roots of Grewia microcos Linn. Journal of Chemical and Pharmaceutical Research, 5(7), 80-87.

Li, H.B., Wong, C.C., Cheng, K.W. and Chen, F. (2008). Antioxidant properties in vitro and total phenolic contents in methanol extracts from medicinal plants. Journal of Food Science and Technology, 41(3), 385 -390. https://doi.org/10.1016/j.lwt.2007.03.011

Liguori, I., Russo, G., Curcio, F., Bulli, G., Aran, L., Della-Morte, D., Gargiulo, G., Testa, G., Cacciatore, F., Bonaduce, D. and Abete, P. (2018). Oxidative stress, aging and diseases. Clinical Interventions in Aging, 13, 757-772. https://doi.org/10.2147/ CIA.S158513

Nascimento, A.K.L., Melo-Silveira, R.F., Dantas-Santos, N., Fernandes, J.M., Zucolotto, S.M., Rocha, H.A.O. and Scortecci, K.C. (2013). Antioxidant and antiproliferative activities of leaf extracts from Plukenetia volubilis Linneo (Euphorbiaceae). Evidence-Based Complementary and Alternative Medicine, 2013, 950272. https:// doi.org/10.1155/2013/950272

Pallab, K., Barman, T.K., Pal, T. and Kalita, R. (2013). Estimation of total flavonoids content (TFC) and antioxidant activities of methanolic whole plant extract of Biophytum sensitivum linn. Journal of Drug Delivery and Therapeutics, 3(4), 33-37. https:// doi.org/10.22270/jddt.v3i4.546

Pattanayak, S.P., Mazumder, P.M. and Sunita, P. (2011). Total phenolic content, flavonoid content and in vitro antioxidant activities of Dendrophthoe falcata (L.f.) Ettingsh. Research Journal of Medicinal Plant, 6(2), 136-148. https://doi.org/10.3923/ rjmp.2012.136.148

Quettier, D.C. (2000). Phenolic compounds and antioxidant activities of buckwheat hulls and flour. Journal of Ethnopharmacology, 72(1-2), 35-42. https://doi.org/10.1016/S0378-8741(00)00196-3

Re, R., Pellegrini, N., Proteggente, A., Pannala, A.,
Yang, M. and Rice-Evans, C. (1999). Antioxidant activity applying an improved ABTS radical cation decolourization assay. Free Radical Biology and Medicine, 26(9-10), 1231-1237. https:// doi.org/10.1016/S0891-5849(98)00315-3

Saxena, M., Saxena, J., Nema, R., Singh, D. and Gupta, A. (2013). Phytochemistry of medicinal plants. Journal of Pharmacognosy and Phytochemistry, 1 (6), 168-182.

Schvab, M.C., Ferreyra, M.M., Davies, C.V., Stefani, A., Cayetano, M.C., Gerard, L.M. and Gonzalez, R.F. (2015). Effects of orange winemaking variables on antioxidant activity and bioactive compounds. Journal of Food Science and Technology, 35(3), 407 -413. https://doi.org/10.1590/1678-457X.6571

Soobrattee, M., Neergheen, V., Luximon-Ramma, A., Aruoma, O. and Bahorun, T. (2005). Phenolics as potential antioxidant therapeutic agents: Mechanism and actions. Mutation Research, 579(1-2), 200-213. https://doi.org/10.1016/j.mrfmmm.2005.03.023

Srichamnong, W., Ting, P., Pitchakarn, P., Nuchuchua, O. and Temviriyanukul, P. (2018). Safety assessment of Plukenetia volubilis (Inca peanut) seeds, leaves and their products. Food Science and Nutrition, 6(4), 962-969. https://doi.org/10.1002/fsn3.633

Tiwari, P., Kumar, B., Kaur, M., Kaur, G. and Kaur, H. (2011). Phytochemical screening and extraction: a review, Internationale Pharmaceutica Sciancia, 1 (1), 98-106.

Tomsone, L., Kruma, Z. and Galoburda, R. (2012). Comparison of different solvents and extraction methods for isolation of phenolic compounds from Horseradish roots (Armoracia rusticana). International Journal of Biological, Biomolecular, Agricultural, Food and Biotechnological Engineering, 6(4), 236-241.

Uddin, M.S., Hossain, M.S., Mamun, A.A., Tewari, D., Asaduzzaman, M., Ialam, M.S. and Abdel-Daim, M.M. (2020). Phytochemical analysis and antioxidant profile of methanolic extract of seed, pulp and peel of Baccaurea ramiflora Lour. Asian Pacific Journal of Tropical Medicine, 11(7), 443450.

Wang, S., Zhu, F. and Kakuda, Y. (2018). Sacha inchi (Plukenetia volubilis L.): Nutritional composition, biological activity and uses. Food Chemistry, 265, 316-328.

https://doi.org/10.1016/ j.foodchem.2018.05.055

Waterman, P.G. and Mole, S. (1994). Analysis of phenolic plant metabolites. Oxford: Blackwell Science Publishing.

Wickens, A.P. (2001). Ageing and the free radical 
theory. Respiration Physiology, 128(3), 379-391.

https://doi.org/10.1016/S0034-5687(01)00313-9

Wuttisin, N. (2017). Fatty acid composition of Sacha inchi (Plukenetia volubilis L.) oil and efficacy of Sacha inchi lotion. Journal of Science and Technology Ubon Ratchathani University, Special Issue September, 120-127.

Wuttisin, N. and Boonsook, W. (2019). Total phenolic, flavonoid contents and antioxidant activity of Siraitia grosvenorii fruits extracts. Food and Applied Bioscience Journal, 7(Special Issue on Agriculture and Agro-Industry), 131-141. 